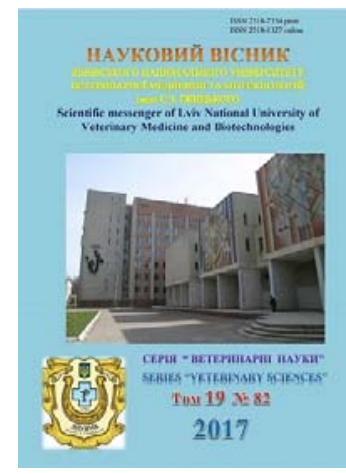

Науковий вісник Львівського національного університету ветеринарної медицини та біотехнологій імені С.3. Гжицького

Scientific Messenger of Lviv National University of Veterinary Medicine and Biotechnologies

doi:10.15421/nvlvet8225

ISSN 2518-7554 print

ISSN 2518-1327 online

http://nvlvet.com.ua/

УДК 591.471.34/.473:598.281

\title{
Біоморфологія м'язів, діючих на плечовий суглоб чорнодзьобої гагари
}

\author{
О.О. Мельник, М.В. Мельник \\ melnik_oo@nubip.edu.ua \\ Національний університете біоресурсів і природокористування Украӥни, \\ вул. Полковника Потехіна, 16, м. Київ, 03041, Украӥна
}

\begin{abstract}
У статті наведені результати досліджень біоморфологічних особливостей м'язів, діючих на плечовий суглоб деяких представників ряду гагароподібних Ordo Gaviiformes. Плечовий суглоб птахів є багатовісним суглобом, рухи в якому забезпечують не лише м'язи власне плечового суглоба, але й деякі м'язи плечового поясу та ліктьового суглоба. Варто зазначити, що головними м'язами польоту птахів є м'язи плечового поясу, зокрема: грудний та надкоракоїдний. Важливе значення мають і деякі з м'язів ліктьового суглоба, зокрема коракоїдно-променевий та лопатко-триголовий. Це підтверджується як точками фіксачії, так і ступенем їх розвитку. Ступінь розвитку і диференціачії м'язів, діючих на плечовий суглоб є різними, щьо обумовлено особливостями функціонування крила під час польоту, а у водоплавних птахів - $і$ особливостями підводного плавання з використанням крил.

Метою даного біоморфологічного дослідження було розуміння ступеня розвитку, а головне - механізмів диференціації та трансформації м'язів, діючих на плечовий суглоб птахів, пристосованих до водного середовища існування.

Матеріал для досліджень було одержано із фондів кафедри анатомії тварин ім. акад. В.Г. Касьяненка Начіонального університету біоресурсів і природокористування України, де і були проведені дослідження м'язових структур плечового суглоба представника ряду гагароподібних - чорнодзьобої гагари Gavia iтmеr у кількості 3-х особин. Птахи ряду гагароподібних характеризуються швидким, але мало маневреним польотом. Вони надзвичайно чудово пристосовані до водного середовища і більшу частину свого життя проводять у воді, виходячи на сушу лише в період гніздування. Ці птахи чудово плавають та пірнають і під час підводного плавання користуються не лише тазовими кінцівками, а й крилами. Це своєю чергою, накладає певні відбитки на ступінь розвитку і диференціації досліджуваних груп м'язів. Встановлено, щуо серед досліджених груп м'язів (плечового пояса, плечового та ліктьового суглобів) найбільш розвинутою є група м'язів плечового пояса - 86\%. Суттево меншими є групи м'язів ліктьового 8,5\% та плечового - 5,4\% суглобів. Крім того, нами вперше встановлено, що найбільший за свойм розвитком серед всіх досліджених м'язів - грудний м'яз (група м'язів плечового пояса) має суттєві відмінності порівняно з іншими видами птахів. Ці відмінності полягають у тому, щзо даний м'яз чітко диференційований на два окремих пласти, фактично два окремих м'язи - поверхневий та глибокий, більше з яких розвинутий поверхневий. Така диференціація обумовлена біоморфологічними адаптаціями до середовища існування.
\end{abstract}

Ключові слова: біоморфологія, плечовий суглоб, м'язи, птахи, гагароподібні, чорнодзьоба гагара, крило.

\section{Биоморфология мышц, действующих на плечевой сустав черноклювой гагары}

\author{
О.О. Мельник, М.В. Мельник \\ melnik_oo@nubip.edu.ua
}

Национальный университет биоресурсов и природопользования Украинь,, ул. Полковника Потехина 16, Киев, 03041, Украина

В статье приведены результаты исследований биоморфологических особенностей мыши, действующих на плечевой сустав некоторых представителей отряда гагарообразных Ordo Gaviiformes. Плечевой сустав птии, является многоосным

Citation:

Melnyk, O.O., Melnyk, M.V. (2017). Biomorphology of muscle acting on the shoulder joint of common loon. Scientific Messenger LNUVMB, 19(82), $120-124$. 
суставом, движения в котором обеспечивают не только мышиы собственно плечевого сустава, но и некоторые мышиы плечевого пояса и локтевого сустава. Следует отметить, что главными мышиами полета птии являются мышиь плечевого пояса, в частности: грудная и надкоракоидная. Важное значение имеют и некоторые из мыли локтевого сустава, в частности коракоидно-лучевая и лопаточно-трехглавая. Это подтверждается как точками фиксации, так и степенью их развития. Степень развития и дифференциации мыши, действуюших на плечевой сустав различны, что обусловлено особенностями функционирования крыла во время полета, а у водоплаваюших птии - и особенностями подводного плавания с использованием крыльев.

Целью данного биоморфологического исследования было понимание степени развития, а главное механизмов дифференцчиачии и трансформации мышиц действующих на плечевой сустав птич приспособленных к водной среде обитания.

Материал для исследований были получены из фондов кафедры анатомии и гистологии жсвотных им. акад. В.Г. Касьяненко Начионального университета биоресурсов и природопользования Украины, где и были проведены исследования мышечных структур плечевого сустава представителя отряда гагарообразных - чорноклювой гагары Gаvіа іттег в количестве 3-х особей. Птииьы отряда гагаропообразных характеризуются быстрым, но мало маневренным полетом. Они чрезвычайно прекрасно приспособлены к водной среде и большую часть своей жизни проводят в воде, выходя на суиу только в период гнездования. Эти птицы прекрасно плавают и ныряют и во время подводного плавания пользуются не только тазовыли конечностями, но и крыльями. Это, в свою очередь, накладывает определенные отпечатки на степень развития и дифференцииции исследуемых групп мышц. Установлено, что среди исследованных групп мыши (плечевого пояса, плечевого и локтевого суставов) наиболее развитой является группа мыши плечевого пояса - $86 \%$. Сушественно меньшей есть группы мыши локтевого 8,5\% и плечевого - 5,4\% суставов. Кроме того, нами впервые установлено, что наибольшая по своему развитию среди всех исследованных мыши - грудная мышия (группа мыши плечевого пояса) имеет существенные отличия по сравнению с другими видами птиц. Эти различия заключаются в том, что данная мышица четко дифференцирована на два отдельных пласта, фактически две отдельные мышиь - поверхностную и глубокую, наиболее из которых развита поверхностная. Такая дифференциачия обусловлена биоморфологическими адаптациями к среде обитания.

Ключевые слова: биоморфология, плечевой сустав, мышиы, птицы, гагарообразные, чорноклювая гагара, крыло.

\title{
Biomorphology of muscle acting on the shoulder joint of common loon
}

\author{
O.O. Melnyk, M.V. Melnyk \\ melnik_oo@nubip.edu.ua
}

\begin{abstract}
National University of life and environmental sciences of Ukraine,
Polkovnyka Potekhyna Str., 16, Kyiv, 03041, Ukraine
\end{abstract}

The article presents the results of studies of the biomorphological features of muscles acting on shoulder joint of some representatives of order Gaviiformes. Shoulder joint is a multifaceted joint, movements of which are provided not only by the muscles of the shoulder joint itself, but also some muscles of the shoulder girdle and elbow joint. It should be noted that the main muscles of the flight of birds are muscles of the shoulder girdle, in particular: thoracic and m. supracoracoideus. Also important are some of the muscles of the elbow, in particular m.coraco-radialis and $m$. scapula-triceps This is confirmed both by the points of fixation, and the degree of their development.

The degree of development and differentiation of muscles acting on the shoulder joint is different, which is due to the peculiarities of the wing operation during the flight, and in waterfowl-peculiarities of underwater swimmingusing wings. The aim of this biomorphological study was understanding of development degree, and the main, mechanisms of differentiation and transformation of muscles acting on the shoulder joint of birds adapted to the aquatic habitat.

Material for research was obtained from the funds of the Department of anatomy of Animals named after acad. V.G. Kasyanenko of the National University of Life and Environmental Sciences of Ukraine, where the muscle structures of the shoulder joint were studied on black-tailed gagar Gavia immer in number of 3 individuals. Birds of Gaviiformes order are characterized by a rapid, but little maneuverable flight. They are extremely well adapted to the aquatic environment and spend most of their lives in the water, leaving on land only during breeding. These birds perfectly swim and dive, and during diving use not only the pelvic fins but also the wings. This, in turn, imposes certain imprints on the degree of development and differentiation of the studied muscle groups. It was found that among the studied groups of muscles (shoulder girdle, shoulder and elbow joints) the most developed group of muscles is shoulder girdle $-86 \%$. The muscle groups of the elbow $-8.5 \%$ and the shoulder $-5.4 \%$ of the joints are significantly less. In addition, for the first time, we have found that the largest in its development among all the muscles examined-the thoracic muscle (the group of muscles of the shoulder girdle) has significant differences in comparison with other species of birds. These differences consist in the fact that this muscle is clearly differentiated into two separate layers, in fact two separate muscles - superficial and deep, most of which are developed superficial. Such a differentiation is due to biomorphological adaptations to the habitat.

Key words: biomorphology, shoulder joint, muscles, birds, Gaviiformes, Loon, wing.Common loon.

\section{Ветуп}

Плечовий суглоб птахів - це багатовісний суглобом, рухи в якому забезпечують не лише м'язи власне плечового суглоба, а й деякі м'язи плечового пояса, плечового та ліктьового суглобів. Варто зазначити, що головними м'язами польоту птахів є м'язи плечового пояса, зокрема грудний та надкоракоїдний. Важливе значення мають і деякі з м'язів ліктового сугло- ба, зокрема коракоїдно-променевий та лопаткотриголовий.

Все тіло переважної більшості сучасних або віялохвостих птахів характеризується рисами спеціалізації та пристосування до певного способу життя, у переважній більшості випадків, насамперед до польоту. Що стосується гагар, то вони, поряд з цим пристосовані до виключно водного середовища існування. Ці птахи є надзвичайно чудовими плавцями, що практи- 
чно не можуть ходити по суші та виходять на неї тільки в період розмноження.

Початок морфологічного вивчення сучасних птахів був покладений фундаментальними роботами М. Фюрбрінгера, Х. Гадова і Е. Селенки (Fürbringer, 1888; Gadow and Selenka, 1893; Fürbringer, 1902). Розглядаючи як кінцеву мету своїх досліджень розробку зоологічної систематики, ці автори акцентували увагу на порівняльно-анатомічних особливостях м'язовоскелетних елементів у окремих представників всіх рядів класу птахів. Докладний опис топографії і макроскопічної будови складових плечового суглоба, виконаний М. Фюрбрінгером (Fürbringer, 1888), продовжує залишатися донині основою для формування загальних і конкретних уявлень про його анатомію у представників окремих рядів тварин, зокрема і представників класу птахів.

Менш об'ємна як за кількістю досліджених видів, так i за деталями морфологічної характеристики м'язово-скелетних структур є робота Х. Гадова i Е. Селенки (Gadow and Selenka, 1891), що відрізняється більш різностороннім підходом до аналізу результатів, зокрема за рахунок функціональної інтерпретації морфологічних даних.

Варто відмітити, що найбільша кількість робіт 3 вивчення м'язово-скелетних структур сучасних птахів проведена переважно на свійській птиці (курях та перепілках). Ця тенденція зберігається і нині (Kale, 1982; Boev, 1986; Moroz, 2003). Разом з тим, із більш сучасних порівняльно-анатомічних робіт, присвячених вивченню птахів, слід відмітити роботу В.Ф. Сича (Syich, 1999) та деякі роботи щодо вивчення плечового суглоба як викопних, так і сучасних птахів (Melnyk, 2009; Melnyk, 2013; Melnyk and Kostiuk, 2013; Kostiuk and Melnyk, 2016).

\section{Матеріал і методи досліджень}

Матеріалом для досліджень слугували фіксовані $10 \%$ розчином формаліну трупи чорнодзьобої гагари - Gavia immer у кількості 3 особини, одержані з фондів кафедри анатомії тварин ім. акад. В.Г. Касьяненка Національного університету біоресурсів і природокористування України. На трупах проводилось звичайне анатомічне препарування м'язів плечового суглоба. Після опису точок фіксації м'язів кожен м'яз розсікали з метою виявлення наявності або відсутності перистості, також проводилось зважування кожного окремого м'яза. Отримані цифрові дані були оброблені статистично.

\section{Результати та їх обговорення}

Птахи ряду гагароподібних характеризуються швидким, але маломаневреним польотом, проте $\epsilon$ надзвичайно пристосованими до водного середовища. Основним локомоторним органом цих птахів під час підводного плавання є тазові кінцівки, однак, користуються вони і крилами, що накладає свої відбитки на ступінь розвитку і диференціації досліджуваних м’язів (рис. 1-2).

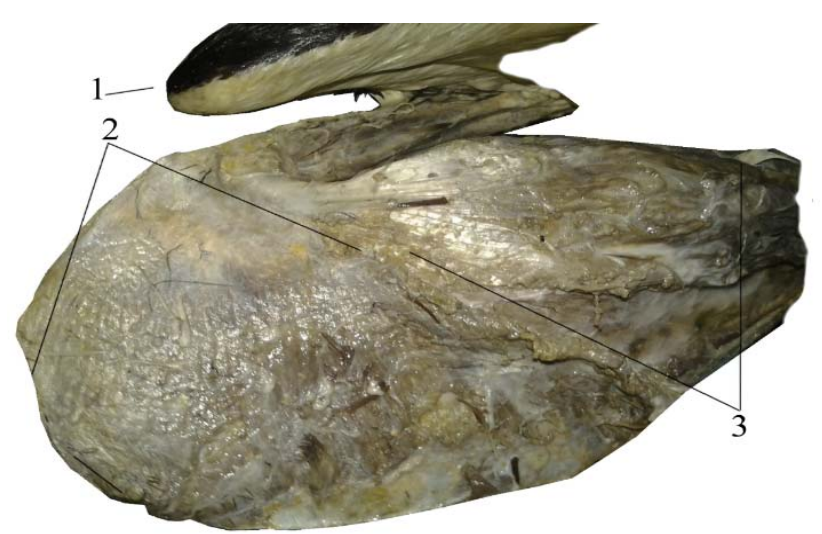

Рис. 1. М'язи плечового пояса чорнодзьобої гагари: 1 - крило; 2 - поверхневий грудний м'яз; 3 - глибокий грудний м'яз

У чорнодзьобої гагари серед м'язів плечового пояса передній ромбоподідний м'яз відсутній. Однак чітко виражений задній ромбоподібний м'яз. Він починається м'язово від остистих відростків 3-го - 5- го грудних хребців та закінчується на дорсальному краї каудальної частини лопатки.

У гагароподібних, як і у більшості досліджених птахів, є два найширших м'язи спини - передній та задній, що мають типові для птахів точки фіксації. Однак більш розвинутим є задній. Слід зазначити, що на відміну від переднього найширшого каудальний найширший м'яз спини закінчується апоневротично i невіддиференційований від медіальної поверхні лопатко-триголового м'яза плеча.

Із зубчастих м'язів, яких у більшості птахів є три, даному виду притаманний лише один - слаборозвинутий каудальний зубчастий м'яз. Цей м'яз чітко диференційований на два зубці і закінчується в ділянці каудального кінця лопатки. Краніальний та середній (глибокий) зубчасті м'язи у даного виду трансформовані в апоневрози.

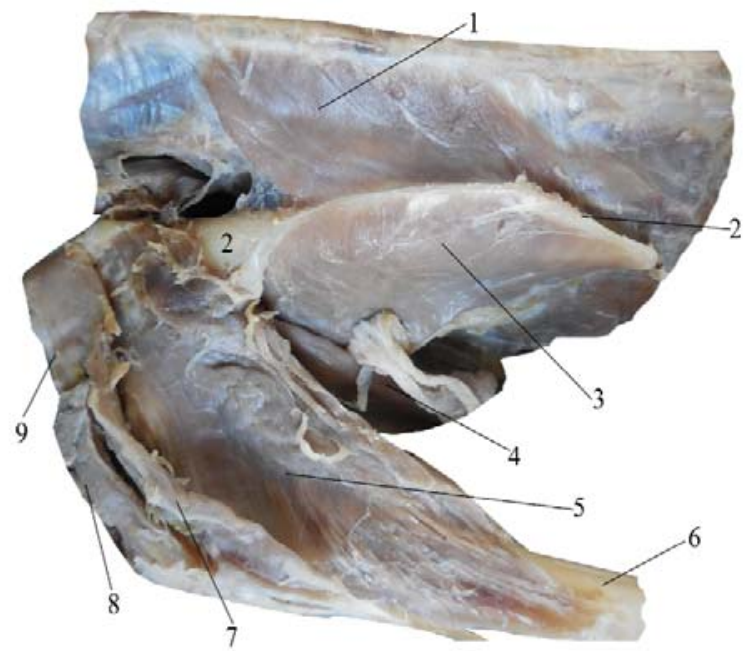

Рис. 2. М'язи плечового пояса, плечового та ліктьового суглобів чорнодзьобої гагари: 1 - ромбоподібний м'яз; 2 - лопатка; 3 - надлопатковий м'яз; 4 - грудний м'яз; 5 - дельтоподібний м'яз; 6 - плечова кістка; 7 - довга голівка коракоїднопроменевого м'яза; 8 - коротка голівка коракоїдно променевого м'яза; 9 - коракоїдно-променевий м'яз. 
Грудний м'яз у дослідженого виду чітко диференційований на два окремих пласти, фактично два окремих м'язи - поверхневий та глибокий, більше 3 яких розвинутий поверхневий. М'язові волокна поверхневого грудного м’яза (пласта) мають вентральний напрямок, а глибокого - каудальний.

Основна частина надкоракоїдного м'яза лежить під поверхневим грудним м'язом, фіксується від вентральної поверхні коракоїда та кіля грудної кістки. Закінчується м'яз сухожильно на латеральній поверхні медіального горба плечової кістки. Варто зазначити, що за розташуванням м'язових волокон він $є$ двоперистим.

Підкоракоїдний м'яз у даного виду за точками фіксації є типовим для птахів.

М'язи плечового суглоба гагароподібних представлені меншою кількістю ніж це спостерігається у багатьох інших видів. Так, підлопатковий м'яз починається м'язово від медіальної поверхні краніальної половини лопатки і закінчується сухожильно на медіальному горбі плечової кістки. Лопатко-плечовий м'яз (надлопатковий м'яз) на краніальний та каудальний не диференціюється. Починається він м'язово на латеральній поверхні лопатки. Однак на відміну від підлопаткового, початок якого займає лише краніальну половину медіальної поверхні лопатки, початок цього м'яза займає всю латеральну поверхню лопатки. Закінчується він м'язово-апоневротично на медіальному горбі плечової кістки. Варто зазначити, що надлопатковий м'яз розвинутий дещо більше, ніж підлопатковий.

Дельтоподібний м'яз починається сухожильно на латеральній поверхні лопатки та на проксимальному кінці вилочки. Закінчується він апоневротично в ділянці проксимальної частини дорсальнох поверхні дельтоподібного гребня плечової кістки. Варто зазначити, що серед м'язів плечового суглоба дослідженого виду дельтоподібний м'яз є найбільш розвинутим.

У досліджених гагароподібних виділяється два чітко диференційованих коракоїдно-плечових м'язи передній та задній. Передній коракоїдно-плечовий м'яз починається сухожильно від проксимального кінця коракоїда і закінчується м'язово в ділянці дельтоподібного гребеня плечової кістки. Задній коракоїдно-плечовий м'яз бере початок значно нижче - від коракоїдно-стернальної частини грудної кістки та дистальної половини коракоїда. Закінчується він сухожильно на медіальному горбі плечової кістки. За ступенем розвитку він більш розвинутий, ніж передній коракоїдно-плечовий м'яз.

Ключично-плечовий м'яз починається м'язово від латеральної поверхні проксимального кінця вилочки та закінчується сухожильно в ділянці дельтоподібного гребня плечової кістки.

Група м'язів ліктьового суглоба гагароподібних має певну специфіку їхньої диференціації та фіксації. Зокрема, лопатко-триголовий м'яз починається м'язово-сухожильно від краніальної третини латеральної поверхні лопатки та сухожильно від медіального горба плечової кістки. Закінчується він на ліктьовому горбі ліктьової кістки. У птахів, крім лопаткотриголового м'яза плеча, що є аналогом довгої голівки триголового м'яза плеча ссавців, є ще й латеральний та медіальний плече-триголові м'язи. Ці м'язи $є$ аналогами латеральної та медіальної голівок того ж таки триголового м'яза плеча ссавців. Однак у досліджених гагароподібних ці два м'язи є недиференційованими і являють собою один плече-триголовий м'яз. Проксимальна частина цього м'яза чітко диференційована на латеральну та медіальну голівки, що мають типові точки фіксації.

Пропатагіальний м'яз, або напружувач літальної перетинки, починається м'язово від проксимального кінця вилочки та апоневротично від дельтоподібного гребеня плечової кістки. В ділянці дельтоподібного гребеня м'язові волокна пропатогіального м'яза переходять у еластичний сухожилок, що закінчується в ділянці кисті. Крім того, в тій же ділянці даний м'яз переходить у сухожилок, що своєю чергою переходить у тоненький апоневроз, який закінчується на м'язах передпліччя.

Коракоїдно-променевий м'яз починається сухожильно на проксимальному кінці коракоїда. Він характеризується коротким м'язовим черевцем та довгим сухожилком, який закінчується на латеральній поверхні проксимального кінця променевої кістки. Варто зазначити, що в ділянці дельтоподібного гребеня плечової кістки м'язове черевце цього м'яза слабо диференційоване від плечового м'яза. Своєю чергою, плечовий м'яз бере м'язовий початок від дельтоподібного гребеня плечової кістки і закінчується на медіальній поверхні проксимального кінця променевої кістки.

Співвідношення досліджених м'язів наведено у таблиці 1.

Табличя 1

Співвідношення маси м'язів до загальної маси їх м'язових груп, \%

\begin{tabular}{|c|c|c|c|c|c|}
\hline \multicolumn{6}{|c|}{ М'язи } \\
\hline \multicolumn{2}{|l|}{ Плечового пояса } & \multicolumn{2}{|l|}{ Плечового суглоба } & \multicolumn{2}{|l|}{ Ліктьового суглоба } \\
\hline 1 & 2 & 3 & 4 & 5 & 6 \\
\hline Задній ромбоподібний & 0,3 & Підлопатковий & 13,1 & Коракоїдно-променевий & 13,0 \\
\hline Передній найширший & 0,5 & Краніальний надлопатковий & 17,2 & Лопатко-триголовий & 32,6 \\
\hline Задній найширший & 2,1 & Дельтоподібний & 34,5 & Плече-триголовий & 21,7 \\
\hline Грудний & 84,7 & Задній коракоїдно-плечовий & 14,6 & Прапатагіальний & 32,6 \\
\hline Надкоракоїдний & 8,6 & Ключично-плечовий & 9,9 & & \\
\hline Підкоракоїдний & 3,0 & & & & \\
\hline
\end{tabular}


Певні особливості спостерігаються і у співвідношенні м'язових груп, що діють на плечовий суглоб гагароподібних, таблиця 2. Проведені дослідження показують, що грудний м'яз у гагароподібних чітко диференційований на два пласти - поверхневий i глибокий, що характеризуються різним напрямком м'язових волокон.

Краніальний та каудальний лопатко-плечові м'язи у гагароподібних не диференційовані між собою і $є$ одним лопатко-плечовим м'язом, що описано вперше нами.

Всі зазначені особливості будови та диференціації м'язів, діючих на плечовий суглоб птахів, обумовлені фізичними навантаженнями, що сприченені біоморфологічними адаптціями до типу, швидкості та тривалості польоту, а також використанням крил під час підводного плавання.

Табличя 2

Співвідношення маси м'язових груп, що діють на плечовий суглоб гагароподібних до їх загальної маси, \%

\begin{tabular}{|l|c|c|c|c|}
\hline \multirow{2}{*}{$№$ п/п } & \multirow{2}{*}{ Вид птахів } & \multicolumn{3}{|c|}{ Групи м’язів } \\
\cline { 3 - 5 } & Чорнодзьоба гагара & Плечового поляса & Плечового суглоба & Ліктьового суглоба \\
\hline 1. & Чл,0 & 5,4 & 8,5 \\
\hline
\end{tabular}

\section{Висновки}

1. Плечовий суглоб птахів є багатовісним суглобом, рухи в якому забезпечують не лише м'язи власне плечового суглоба, але й м'язи плечового пояса та деякі м'язи ліктьового суглоба. Головними м'язами польоту птахів є м'язи плечового пояса, зокрема: грудний, що опускає крило та надкоракоїдний, що його піднімає. Це підтверджується як точками фіксації, так і ступенем їх розвитку.

2. Ступінь розвитку і диференціації м'язів, що діють на плечовий суглоб у гагароподібних обумовлено особливостями функціонування крила під час польоту та підводного плавання з використанням крил.

Перспективи подальших досліджень. Подальші біоморфологічні дослідження м'язової системи птахів дадуть можливість встановити дійсні механізми еволюційного становлення, диференціації та трансформації м'язів під впливом гравітаційного поля Землі та пристосування до польоту.

\section{Бібліографічні посилання}

Fürbringer, M. (1888). Untersuchungen zur Morphologie und Systematik der Vögel. Amsterdam.

Fürbringer, M. (1902). Zur vergleichenden Anatomie des Brustschulterapparates und der Schultermuskeln. Z. Naturwiss. 36, 289-736.

Gadow, H., Selenka, E. (1893). Bronn's Klassen und Ordnungen des Thier-Reichs. Systematischer Theil. Leipzig, 2(6), 303.

Gadow, H., Selenka, E. (1891). Bronn's Klassen und Ordnungen des Thier-Reichs. Anatomischer Theil. Leipzig, 1(6), 1008.

Syich, V.F. (1999). Morfologiya lokomotornogo apparata ptits. SPb.-Ulyanovsk: Izdatel Srednevolzhskogo nauchnogo tsentra.

Boev, Z.N. (1986). Morfologiya kostey u ptits. Priroda (NRB). 35(6), 50-55.
Moroz, V.F. (2003). Mekhanizmy funktsionuvannia miazovo-skeletnoi systemy ta zakonomirnosti yii rozvytku u khrebetnykh: dysertatsiia doktora veterynarnykh nauk: 16.00.02. K. (in Ukrainian).

Kale, W. (1982). Recent literature. The American Ornithologists. Union. Supplement to the Auk. 99(1), 24.

Kostiuk, V.K., Melnyk, OO. (2016). Biomorfolohichni Osoblyvosti miaziv polotu deiakykh diatlopodibnykh. «Problemy veterynarnoi medytsyny, yakosti i bezpeky produktsii tvarynnytstva»: zbirnyk materialiv KhIII Mizhnarodnoi nauk.-prakt. konf. prof.-vyklad. skladu ta aspirantiv, prysviachenoi 20-richchiu nabuttia universytetom statusu natsionalnoho. K.: NUBiP Ukrainy, 33-34 (in Ukrainian).

Melnyk, O.O., Kostiuk, V. K. (2013). Stan i perspektyvy vyvchennia biomorfolohii plechovoho suhloba ptakhiv. Naukovo-tekhnichnyi biuleten Instytutu biolohii tvaryn. 14(1/2), 386-392 (in Ukrainian).

Melnyk, O.P. (2009). Skelet plechovoho poiasu holubopodibnykh. Naukovo-tekhnichnyi biuleten Instytutu biolohii tvaryn. 10(1/2), 397-403 (in Ukrainian).

Melnyk, A.O. (2013). About Biomorphology of Birds Shoulder joint. Annual Symposium «Contribution of the Scientific Research to Veterinary Medicine Progress», Faculty of Veterinary Medicine, Bucharest, November, 21-22, 2013. Bucharest, 293-294.

Melnyk, O.P. (2011). Biomorfolohiia plechovoho poiasu khrebetnykh : dysertatsiia doktora veterynarnykh nauk: 16.00.02 (in Ukrainian).

Melnyk, O.O. (2016). Biomorfolohiia miazovoskeletnykh struktur plechovoho suhloba ptakhiv. dysertatsiia na zdobuttia naukovoho stupenia kandydata veterynarnykh nauk. K.: NUBiP Ukrainy (in Ukrainian).

Received 29.09.2017 Received in revised form 30.10 .2017 Accepted 6.11.2017 